\title{
Research on the Network Teaching of Ideological and Political Theory Courses in Universities under the epidemic situation -- Take Guangzhou Nanyang Polytechnic College as an example
}

\author{
Li $\operatorname{Yan}^{1}$ \\ ${ }^{1}$ Guangzhou Nanyang Polytechnic College, Guangzhou 510925, China
}

\begin{abstract}
The sudden outbreak of COVID-19 is unprecedented in its scope and impact. Under the epidemic situation, the special "classroom" under the completely virtual state brought by the implementation of network teaching brings challenges and tests to the ideological and political theory course teaching in colleges and universities, and also provides an opportunity for reform and innovation.

Ideological and political theory course is a key course for the implementation of moral education. In the prevention and control of COVID-19 epidemic, it plays a role in the publicity and education of college students and the guidance of public opinion. For the further implementation of xi jinping, general secretary of COVID - 19 epidemic prevention and control of a series of important speech and the important instructions instructions spirit, and the Ministry of Education "closed on teaching, not suspended" requirements, our hospital rapid response, positive response, to carry out the ideological and political theory course network teaching boost war "epidemic" confidence, to ensure the successful completion of the teaching task. In this process, the author realized the shortcomings of our school's horse academy in information literacy, high-quality online course construction and other aspects, and made clear the direction of reform and innovation.
\end{abstract}

\section{The introduction}

Since December 2019, China has experienced an unprecedented outbreak of the super virus, which the World Health Organization has named 2019-NCOV, or COVID-19 for short. As of March, the number of infected people across the country has exceeded 80,000 , and the death toll has exceeded 3,000. The virus is merciless and people have feelings! During the epidemic, a total of 344 medical teams, totaling 42,600 people, were sent to Wuhan. The PLA dispatched three batches of more than 4,000 medical personnel to assist Wuhan, forming a supporting force consisting of forward guidance teams, joint logistic support forces and first-line medical personnel, as well as countless volunteers, community personnel and other first-line personnel to fight the epidemic. Go where there is epidemic, fight it till it perishes. The central committee of the communist party of China issued "on strengthening the party's leadership, to win the epidemic war provide strong political guarantee notice, emphasis on the masses of party members to carry on take the bull by the horns, the spirit of selfless dedication, stands firmly in the first line epidemic prevention and control, do where task XianChong there are strong and work of the party organization, there are party members, as a role model in pioneer.
Guangzhou nanyang technological vocational college conscientiously follow the superior departments in prevention and control work deployment, strictly implement the prevention and control main body responsibility, catch fine emphasizing the prevention and control work, strengthen the bear mission, a clear division of responsibility, initiative, scientific and prudent attitude, grasp the real fine opening preparation, further strengthen the prevention and control in schools, implement the safety precautions and go all out to win the disease prevention and control and classes start the fight, to ensure that the epidemic prevention and control and education teaching. Since the start of March 2020, to implement and carry out the prevention and control of Guangdong province education department will be coronavirus pneumonia outbreak work leading group relevant teaching work notice, resolutely responded to an appeal by the state and in accordance with the "delayed back to school, the normal teaching, advantage, quality" principle, with "the outbreak of war, not suspended" as an opportunity to integrate course resources in our school, to the super star company recommended many boutique online open courses, the first provincial high-quality goods online open courses in our school, film and television synthesis, silver online success online learning and learning platform, provides the high quality courses for the general college students and social resources.

The college requires teachers to make full use of the 
network platform, WeChat, QQ and other information technology tools to actively carry out online teaching. Under the unified organization of the Ideological and Political Education Center of the Student Development Department, the college has carried out a series of webcam themed class meetings with the theme of "Starting from me to fill in the accurate report of scientific epidemic prevention". A number of themed class meetings with novel forms and close to the needs of the current epidemic situation have been held, covering all the students. The school calls on all teachers, students, staff and parents to maintain a calm and calm state of mind and not to panic while protecting their health. We believe that the Party and the government are capable of coping with the epidemic and that our country will win the epidemic prevention and control battle to ensure the normal operation of routine teaching.

\section{The epidemic brings challenges to ideological and political courses}

During the Spring Festival in 2020, the sudden OUTBREAK of COVID-19 disrupted the rhythm of our life, and the whole country was under the shadow of the epidemic. The situation of epidemic prevention and control is grim. In order to better stop the spread of the epidemic, reducing the flow of people is the most effective means of prevention and control. To this end, General Secretary $\mathrm{Xi}$ Jinping has issued important instructions and made every effort to control the spread of the epidemic. The Ministry of Education has also issued a notice, requiring all kinds of schools at all levels to postpone the opening of school, but to suspend classes. Therefore, According to the requirements of the higher authorities and the actual situation, Guangzhou Nanyang Polytechnic Vocational College issued a notice on postponing the opening of the school, and required all grades to carry out online teaching activities according to their actual conditions according to the relevant notice requirements of carrying out online teaching during the epidemic prevention and control period. Epidemic prevention and control is a major test, and the smooth development of ideological and political theory courses in universities is also undergoing tests.

\subsection{The challenge of adaptability of teaching subject}

With the rapid development of information technology, a variety of teaching platforms emerge, such as Super Star Erya, Tencent Classroom, nail, etc. However, some teachers are used to on-site classroom teaching, lack of practical experience in network teaching, and have poor adaptability to network teaching. Coupled with their weak information literacy, they are difficult to express, flexible and efficient control network teaching, and fall into a state of busyness and anxiety, resulting in poor teaching effect. For some students from remote and backward areas, due to the narrow signal coverage and poor family conditions, there are some difficulties in accepting online teaching, which makes students have a low sense of online ideological and political courses. In addition, some teaching platforms are tedious to operate and lack functions, which bring great inconvenience to the use of teachers and students.

Combined with the actual situation of the college, the college requires teachers to make full use of the network platform, WeChat, QQ and other information technology tools to actively carry out online teaching. All secondary school students in development of ideological education center under the unified organization, to "scientific prevention precision required starts from me" as the theme in a series of webcast theme class meeting activity, the school called for the entire school teachers and students to staff and students' parents in the case of make guarantee health protection, stay comfortable serene, don't panic, believe that the party and the government must have enough capacity to deal with the outbreak, we believe that our country will win the epidemic war, to ensure "closed not suspended".

\subsection{The challenge to the teaching supervision and examination mechanism}

During outbreaks, teachers "teaching" in the home, the students "learning" in the home, "teaching" and "learning" of time, space, compared with the field of classroom teaching is more freedom, no strict supervision, and examination mechanism of regulating online education teaching, the teaching quality is difficult to secure, teaching effect is difficult to achieve, for students, online teaching based on network technology, in the moment the media under the situation of rapid spread, students in the use of electronic devices and will inevitably be a variety of extracurricular information interference, for students of serious lack of self-control, let them have more opportunities to use online teaching network platform, In this process, the learning effect of middle school students is certainly greatly reduced.

\subsection{The challenge to practical teaching}

General Secretary Xi Jinping stressed in the symposium of teachers of ideological and political theory course, "We should adhere to the unification of theory and practice, train people with scientific theory, attach importance to the practicality of ideological and political theory course, combine ideological and political class with social class, and educate and guide students to make lofty goals and be striving. The unification of theory and practice is an inevitable requirement for the ideological and political course to carry out the fundamental task of "cultivating people by virtue". Our school practice teaching branch practice teaching and outside practice teaching, Inside practice teaching and outside practice teaching. Due to the epidemic situation, our school could not carry out both extracurricular and off-campus practice teaching. 


\section{Exploration of the teaching path of ideological and Political course in our school during the epidemic period}

During the epidemic period, according to the characteristics of the course and the characteristics of the students in our school, in the teaching of ideological and political theory course, the scientific use of teaching means, overall arrangement of teaching content, reasonable teaching evaluation, and full integration of epidemic elements have completed the teaching task and educational mission.

\subsection{A flipped teaching organization combining network broadcast and platform recording and broadcasting}

The biggest advantage of online teaching is its convenience and speed. It is not limited by time, space or distance. It can accommodate a large number of students online at the same time and can be used to complete teaching tasks directly without leaving home.
In recent years, with the rapid development of new media and new technologies, a variety of live streaming teaching platforms have emerged, transforming the traditional classroom from a "static" mode of unilateral teaching to a "dynamic" mode of two-way interaction between teachers and students. This has promoted the high integration of traditional advantages of ideological and political work with information technology, and enhanced the sense of The Times and attractiveness. Through strict comparison and trial, our school finally chose Tencent Classroom, a professional online education platform, to realize online class teaching for teachers and live interactive learning for students. According to the teaching objectives, teachers assign pre-class learning tasks to students in advance, and then carefully design a synchronized teaching plan for students. Problem-oriented, teachers complete the teaching tasks by answering questions, explaining special topics, interactive exploration, and displaying and reporting. After the live broadcast, I kept close contact with students through super star platform, WeChat group and QQ group to answer questions and solve doubts.

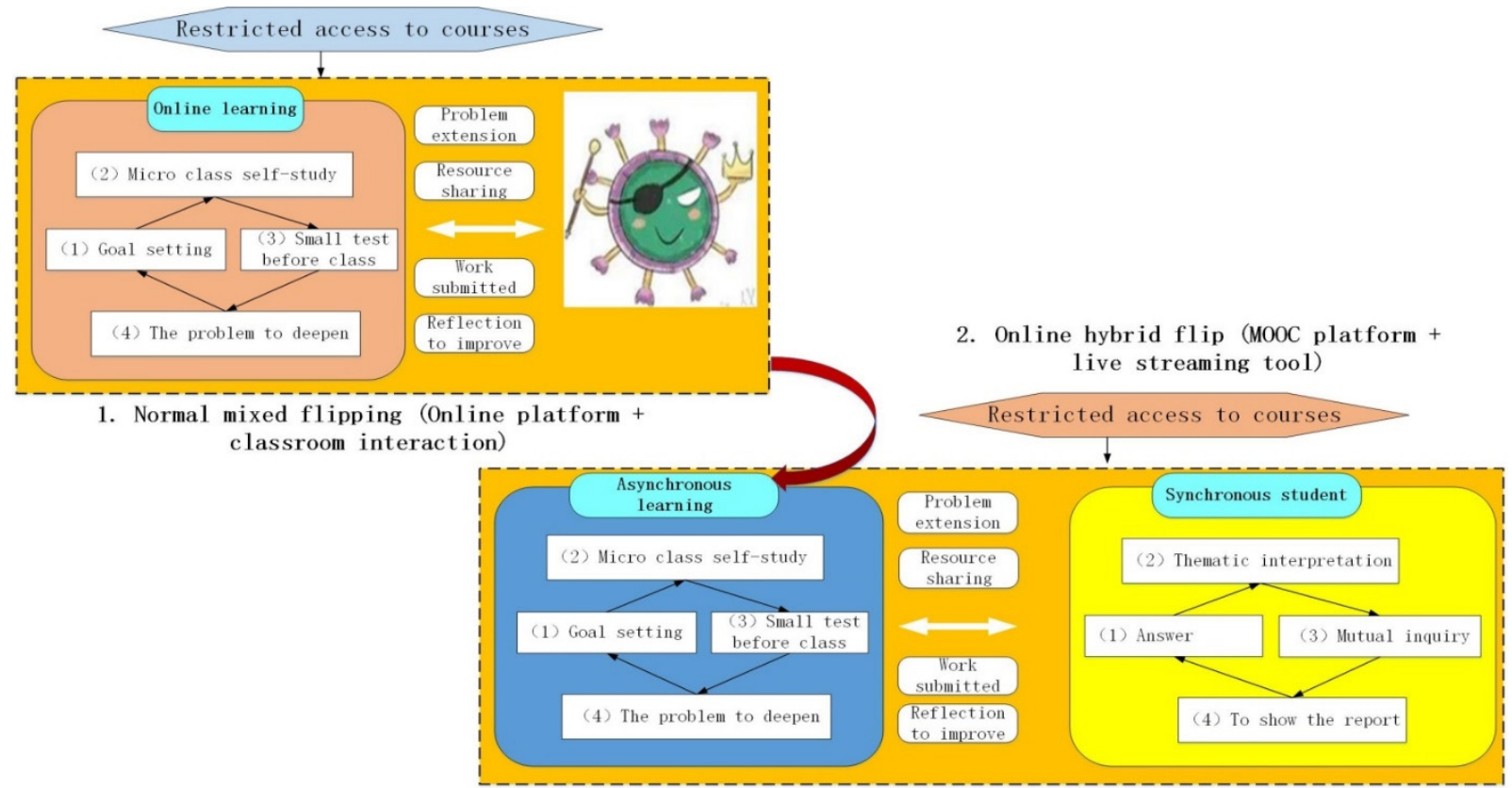

Figure 1. Flipped teaching model for epidemic situation

During the war, the online teaching of ideological and Political theory courses in colleges and universities will create a different "First Class at the beginning of term": 19:30 on March 11, 2020, the first class of ideological and political Theory in the second semester of the 2019-2020 school year will start as scheduled. There is no bell for class, no close contact, only face-to-face online classes for teachers and students. Teachers to "study into the classroom", "living room when the practice room", to create a different "the first class". School leaders, middle-level cadres and teaching supervisors all participate in the first class of the new term and have a comprehensive understanding of online teaching. All teachers actively explore the information means to improve the teaching methods, promote the school curriculum teaching reform, improve the quality of classroom teaching. 


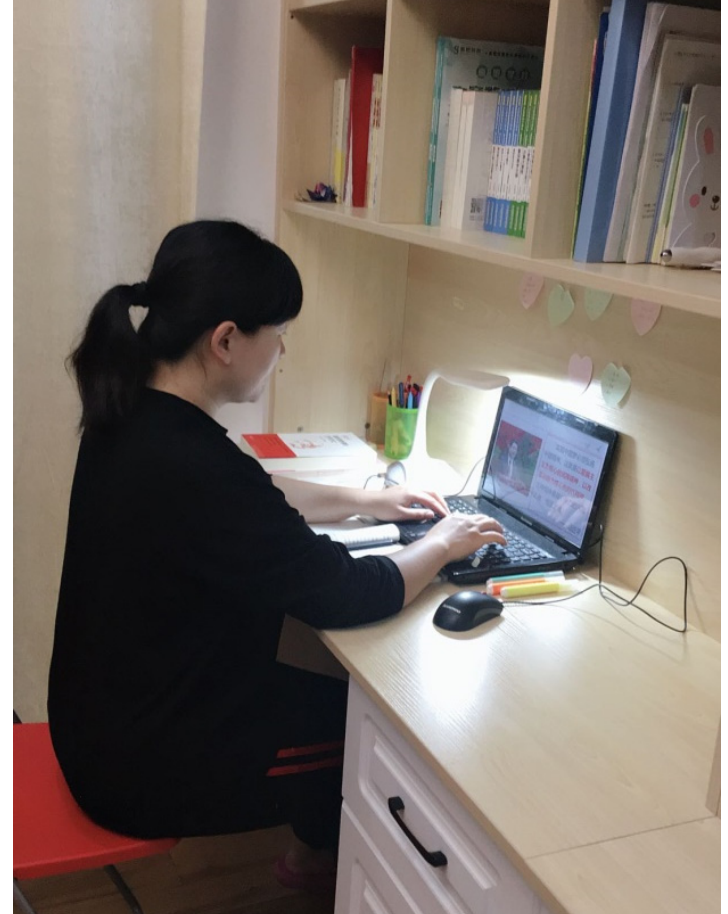

Figure 2. During the battle of "battle", Online teaching creates a different "First Lesson"

The online classroom teaching, 4500 teachers and students in the university are watching The ideological and political theory online class of Yan $\mathrm{Li}$ teacher, for Yan Li teacher is not only a challenge to the traditional teaching, but also an opportunity to learn and improve. Courses on Yan li teacher carefully designed video, vivid teaching courseware, the interpretation of the unique teaching design, make the network teaching content is rich and vivid, warm active classroom atmosphere, teachers and students interact actively, extremely high affinity and appeal, stimulated the students' interest in study, won the students have thumb up and high praise, a new "web celebrity" of the students in their hearts.

Table 1 Teaching Highlights and reflections on online teaching

\begin{tabular}{|c|l|}
\hline \multirow{5}{*}{$\begin{array}{c}\text { Highlight } \\
\text { the }\end{array}$} & $\begin{array}{l}\text { (1) Truly implement the online } \\
\text { teaching mode of "no relaxation } \\
\text { during holidays, no suspension from } \\
\text { school, no teaching without } \\
\text { suspension from class"; }\end{array}$ \\
\cline { 2 - 2 } teaching & $\begin{array}{l}\text { questions by using live or realize the construction of } \\
\text { hyperstar online teaching resources, } \\
\text { provide online guidance and answer } \\
\text { prominent priorities. Check in on } \\
\text { mobile phone } 10 \text { minutes before class, } \\
\text { realize the teaching interaction and } \\
\text { communication of "love is not } \\
\text { separated from screen" in Tencent } \\
\text { classroom and QQ group; }\end{array}$ \\
\cline { 2 - 2 } & $\begin{array}{l}\text { (3) Class cadres should be responsible } \\
\text { for signing in before class, supervising } \\
\text { classroom discipline, strengthening } \\
\text { guidance for students independent }\end{array}$ \\
\hline
\end{tabular}

\begin{tabular}{|c|c|}
\hline & $\begin{array}{l}\text { learning, cultivating students' } \\
\text { self-restraint and control ability, } \\
\text { activating autonomy, enhancing } \\
\text { self-confidence, and improving } \\
\text { life-long self-learning ability. }\end{array}$ \\
\hline \multirow{3}{*}{$\begin{array}{l}\text { Teaching } \\
\text { reflection }\end{array}$} & $\begin{array}{l}\text { (1) Network teaching is a new } \\
\text { teaching mode, which should } \\
\text { strengthen the guidance for students' } \\
\text { independent learning and implement } \\
\text { task-driven learning; }\end{array}$ \\
\hline & $\begin{array}{l}\text { (2) network teaching is affected by the } \\
\text { network speed and objective factors of } \\
\text { teaching platform, especially in the } \\
\text { peak period, teaching resources are } \\
\text { difficult to access, so teaching } \\
\text { courseware and homework can only be } \\
\text { Shared in WeChat groups; }\end{array}$ \\
\hline & $\begin{array}{l}\text { (3) Online guidance and } \\
\text { question-answering are often limited } \\
\text { by time. Within a limited time, I can } \\
\text { only reply to some students' questions } \\
\text { and comment on some students' } \\
\text { homework. }\end{array}$ \\
\hline
\end{tabular}

In addition, after years of construction, our country has built up a good network teaching resources reserves, especially China's education cause development "much starker choices-and graver consequences-in planning, education system, actively promote" Internet + "education, enhance the" master class "" school network classroom" "mail" class "online open courses" and other information-based education teaching and teachers' teaching and research a new mode of exploration and promotion, got unprecedented rich online teaching resources and development. Carefully during the outbreak, the Ministry of Education organization, carefully nurtured, careful selection, introduced a quality assurance, including education courses, 22 online course platform, 24000 courses, facing the whole country all the universities free high-quality online courses and virtual simulation experiment of teaching resources, covers all undergraduate 121 eight disciplines and specialty of higher vocational professional categories, these resources provides strong support for teaching during the outbreak.

In addition to live teaching, our school makes full use of online resources to carry out independent learning, instructing students to watch course videos, questionnaire survey, in-class test, topic discussion, homework submission and after-class q\&A on teaching platforms such as Super Star and Anchor, etc., so as to make a good plan for pre-class, in-class and after-class teaching and ensure the quality of online teaching.

\subsection{A flipped teaching mode combining autonomous learning and teacher's teaching}

Ideological and political course teaching activity is neither a single teacher teaching activity nor a pure student learning activity, but a special practice-cognition compound activity which is organically composed by the teacher teaching activity and the student learning activity caused by it. Whether learning environment entity space 
or online platform, explore the combination of autonomous learning and teachers teaching tilting teaching method is an effective means to realize the goal of education courses teaching, is helpful to exert students' subjective position, make the process of teaching is no longer the teacher instilled established conclusions, but transformed into the problem consciousness, method guidance, the process of teachers and students together to explore the correct conclusion. Look from the level of teachers "teaching", in the process of classroom teaching, teachers are no longer a single "indoctrination" instead of "pilot", explore the teacher's demonstration to empathy transformation, by both transmissive teaching between teachers and students to rev extension teaching mode of teaching, arouse students as independent individuals involved in the knowledge construction, construction of personality and value in the construction, outstanding guide, guide and guiding role, and so true; From the perspective of "learning", students are no longer passive "teachable" but "researchers" of knowledge and "participants" in the classroom learning process. In the online learning process, according to the curriculum outline and teaching content, students independently set up study groups to conduct thematic discussions around learning tasks and learning points, and brainstorm based on the discussion situation. Finally, teachers answer questions and solve doubts.

Student evaluation: While making statistics of the questionnaire data, a large number of students' evaluations and Suggestions on ideological and political course teachers and flipped teaching are collected and summarized. Table 2 below is an excerpt of some students' evaluations and Suggestions on the course "Ideological and Moral Cultivation and Legal Basis".

Table 2 Students' evaluation and Suggestions on and flip teaching

\begin{tabular}{|c|c|c|}
\hline $\begin{array}{c}\text { Student } \\
\text { assessment }\end{array}$ & $\begin{array}{l}\text { Ideological } \\
\text { and moral } \\
\text { cultivation } \\
\text { and legal } \\
\text { basis }\end{array}$ & $\begin{array}{l}\text { Blended learning } \\
\text { mode is used in course } \\
\text { teaching, which } \\
\text { enriches teaching } \\
\text { resources, combines } \\
\text { online and offline, and } \\
\text { adds a large number of } \\
\text { video cases, which } \\
\text { stimulates our interest } \\
\text { in learning; } \\
\text { (2) It increases the } \\
\text { effectiveness } \\
\text { interactivity and } \\
\text { classroom teaching, and } \\
\text { truly reflects the core of } \\
\text { ideological and political } \\
\text { teaching, which focuses } \\
\text { on the thinking of } \\
\text { practical problems, } \\
\text { theory and practice, and } \\
\text { the unification of } \\
\text { subjective and } \\
\text { objective; a large } \\
\text { (3) Through a and }\end{array}$ \\
\hline
\end{tabular}

\begin{tabular}{|c|c|c|}
\hline & & $\begin{array}{l}\text { number of practical and } \\
\text { intuitive videos, it helps } \\
\text { us establish correct } \\
\text { political thinking ability } \\
\text { and distinguish right } \\
\text { from wrong. }\end{array}$ \\
\hline & & $\begin{array}{l}\text { (1) Through blended } \\
\text { learning, our interest in } \\
\text { learning is stimulated in } \\
\text { class, and the } \\
\text { phenomenon of } \\
\text { sleeping and playing } \\
\text { with mobile phones is } \\
\text { almost eliminated; } \\
\text { (2) In class, everyone is } \\
\text { using mobile phones to } \\
\text { complete classroom } \\
\text { activities and cooperate } \\
\text { with teachers to achieve } \\
\text { online interaction, } \\
\text { which is very } \\
\text { interesting }\end{array}$ \\
\hline \multirow{2}{*}{$\begin{array}{c}\text { Student } \\
\text { comments } \\
\text { and } \\
\text { Suggestions }\end{array}$} & \multirow{2}{*}{$\begin{array}{l}\text { Ideological } \\
\text { and moral } \\
\text { cultivation } \\
\text { and } \\
\text { Legal } \\
\text { basis }\end{array}$} & $\begin{array}{l}\text { (1) I hope to further } \\
\text { strengthen the } \\
\text { interaction between } \\
\text { teachers and students. } \\
\text { Since there are a large } \\
\text { number of students in } \\
\text { ideological and Political } \\
\text { education class, I hope } \\
\text { teachers can pay more } \\
\text { attention to the learning } \\
\text { dynamics of each } \\
\text { student after class } \\
\text { through activities, so as } \\
\text { to better answer } \\
\text { questions and solve } \\
\text { doubts online }\end{array}$ \\
\hline & & $\begin{array}{l}\text { The online } \\
\text { resources of flipped } \\
\text { teaching are very rich. } \\
\text { Students can learn after } \\
\text { class, but each student } \\
\text { may have different } \\
\text { understandings of the } \\
\text { same resource. } \\
\text { Therefore, teachers are } \\
\text { expected to increase } \\
\text { more discussions in } \\
\text { classroom teaching, } \\
\text { realize differentiated } \\
\text { and personalized } \\
\text { teaching, and increase } \\
\text { the participation and } \\
\text { autonomy of each } \\
\text { student }\end{array}$ \\
\hline
\end{tabular}

The student investigation of this course shows that compared with traditional teaching, flipped teaching mode can arouse students' learning interest and enthusiasm to a greater extent in the classroom, thus improving the classroom quality and efficiency of 
ideological and political teaching, and subtly leading students' learning. In addition, it cultivates students' good study habits and improves their ability to study independently. The assessment is also more fair and objective.

\subsection{A complete teaching activity combining classroom teaching and practical teaching}

Although practical teaching under the epidemic situation cannot allow students staying at home to carry out social research activities or visit the Red base in person, it can make full use of the rich network resources and various network communication platforms to carry out vivid practical teaching. Education teachers on the Internet to carry out the practice class, for example, you can select the epidemic prevention and control of controversial topics, such as "to the evaluation of every diary," "city is a violation of human rights", etc., and combing all kinds of views on the net, guide students to think, draw their own views, after discussing the correct evaluation by teachers, so it can cultivate the students' thinking, dialectical thinking and system can also make them consciously cacodoxy against network attack, moreover, both can maintain the normal order of online teaching and not depressed students to explore the polarity of thinking independently. Si zheng teachers can also organize students to attack the erroneous remarks made by some Western countries that denigrate and smear China's fight against the epidemic, so as to enhance students' ability to distinguish right from wrong. In addition, the content of after-class teaching can be extended by uploading video resources and questionnaires on the network platform, so as to deepen students' understanding of theoretical knowledge and improve their ability to combine theory with practice and use theory to guide practice. In addition, in the arduous battle against the outbreak, there emerge many reflect the character of "positive energy", such as zhi-ming liu and public security policemen died in disease resistance front, education teacher let the students to write a feeling on the moving story of these heroes, and the public platforms such as weibo, WeChat, QQ on public display, so that the students in the heart touched and shock enhance personal moral cultivation.

\subsection{The teaching design of the organic combination of regular teaching content and epidemic disease elements}

Ideological and political theory course is the key course to realize the fundamental task of cultivating people with morality. Online teaching only changes the form of "teaching" and "learning", and its function of cultivating people with morality cannot be changed for a moment. Ideological and political theory teachers stand at the forefront of moral education, epidemic prevention and control publicity and education, and public opinion guidance. We should combine the epidemic with ideological and political theory teaching and make it close to each other, integrate it into living cases, and change the material of epidemic disease into teaching materials. We should persist in strengthening political consciousness, persist in problem orientation, and innovate the online teaching mode of ideological and political theory course with the sense of gain of college students as the end-result.

In terms of teaching design, combining typical cases in the epidemic prevention and control line, the theoretical depth and practical breadth of the content of teaching materials are expanded to help college students form a rational understanding of fighting against the epidemic, so as to truly put theoretical knowledge into their minds and hearts.

Taking the course of ideological and moral cultivation and Legal Basis as an example, the course of ideological and moral cultivation and legal basis takes "theory application" as the entry point and pays attention to the outlook on life and world outlook guidance at the level of ideological value. In the course teaching, the epidemic response has been integrated into the national, social and individual levels, so that the "small class" of ideological and political courses and the "big class" of the people's war against the epidemic have the same resonance. In terms of outlook on life, it tells the typical cases of real people and real feelings in the fight against coVID-19. It encourages college students to integrate the individual into the larger self, regard selfless dedication to the cause of the country and the people as the highest pursuit of life, and realize the value of life in the struggle of serving the society and contributing to the motherland. In terms of the content of the Chinese spirit, we should make it clear that the Chinese spirit is the soul of rejuvenating the country and strengthening the country, and fully explain the reason, reason and reasoning of the Chinese spirit in the new era. Epidemic prevention and control of the medical workers of selfless dedication, the spirit of scientific research personnel to overcome the difficult, wuhan people's spirit of courage to bear, the tail from wagging the dog, the Chinese people help each other, mutual care, spirit of solidarity, good resistance to plague China's story, Chinese speed, Chinese miracle, reveal behind because of the strength, the spirit of China, China; In terms of moral content, through the analysis of individual moral anomies and lack of public morality reflected in the epidemic, students are guided to be strict with themselves and keep public morality. By telling the stories of compatriots from all walks of life who are dedicated and responsible, students are guided to understand the connotation of professional ethics and enhance their awareness of professional ethics through the power of examples. On the contents of the rule of law, pay attention to from the legislation, law enforcement, judicial, law-abiding, four aspects in this paper, the socialist rule of law system with Chinese characteristics, guide the student to read the usage from knowing, law, research method, four level using the rule of law thought cooperate with and support the epidemic prevention and control work, strengthen the consciousness of university student's consciousness of rule, rule of law and cultivating objective and rational way of legal thinking, practical action to stimulate the whole society with the rule of law thinking, fight the outbreak. 


\subsection{The evaluation system integrating process assessment and result assessment}

The assessment and evaluation of students' academic performance is an important part of ideological and political theory course teaching. Under the epidemic situation, scientific and reasonable assessment and evaluation strategies should be explored to adapt to the situation.

The assessment system of the course needs to pay more attention to the combination of process and results than the normal period, which requires the proportion of assessment indicators to be set at the beginning of the course. The process assessment indicators include attendance, class discussion, learning time, homework, etc., which are comprehensively graded according to a certain percentage. The setting of the result assessment indicators should be scientific and reasonable. In terms of teaching management, it is necessary to strengthen the inspection and assessment of students' online learning effect, shift from tangible management to unbounded management, and timely grasp students' attendance, classroom participation and learning progress according to the big data platform.

\section{Reflection on the reform and development of ideological and political courses brought by the epidemic}

\subsection{Improve teachers' information literacy}

Outbreak of education courses under network teaching exposed education courses in our school teachers' knowledge and application of information technology, build the information-based teaching mode of the era of large data underpowered and lack of teacher training, not only training less, and the training system is incomplete, heavy theory, light practice, form a single, and no specific training, teachers are different levels of information technology teaching ability together unified training is the lack of effect, can also cause some ability level relatively high education courses teachers because of invalid passive to deal with psychological training, not only consumes a lot of time, energy, and money, And seriously reduce the enthusiasm of teachers to learn.

In the future, it is necessary to arouse teachers' subject awareness in teaching practice and mobilize teachers' enthusiasm, initiative and creativity in learning new technologies. Create accurate information technology teaching ability training mode, targeted to strengthen the training of information technology education courses teachers improve network teaching ability and level, speed up the learning of new media technology, filling, actively explore the physical classroom teaching the advantages of traditional and modern information technology education courses of highly integrated teaching new mode and a new scheme, and establish perfect the reward mechanism to promote the information of implementation, such as included in the annual assessment and title appraisal.

\subsection{Speed up the construction of school-based high-quality online courses for ideological and political education}

The construction of high-quality online open course is an educational innovation deeply integrated with modern information technology and teaching. The construction of high-quality online course provides students with a more convenient and efficient teaching mode, rich content and abundant knowledge, which is an important measure of the current teaching reform in colleges and universities. The fine online education courses construction is always adhere to the new era running throughout the thought of socialism with Chinese characteristics, sticking to the marxist ideological positions, pay attention to play a good role of main channel of ideological and political education, general secretary of the jinping series of important speech and the latest theoretical achievements of the communist party of China as a red line, through the teaching and all aspects of the curriculum reform and development, each link, lead the masses of teachers and students understand and grasp its connotation, its implications.

The outbreak, revealed in the boutique online courses in our school building, there are only the MAO zedong thought and Chinese characteristic socialism theory system construction boutique online open course is an introduction to class, in the future, relying on the Ministry of Education proposed by "higher education information 2.0 plan of action and schools promote the building of and comprehensive high-quality goods online open courses as an opportunity, seize the opportunity, innovation, bold design, experiment actively, effort to integrate field of teachers, make full use of the school-based resources, speed up the ideological and moral cultivation and legal basic course, situation and policy class boutique online open course construction process.

\subsection{Deepen curriculum and teaching reform to achieve all-round and in-depth integration}

Under the new teaching form, the college constantly explores more effective online teaching methods and strives to improve the quality of online teaching. Constantly stimulate new thinking, according to the school online teaching work requirements, the implementation of detailed work, fully excavate teachers in the application of information technology in the process of outstanding typical cases, constantly explore innovative management level, work has achieved new results. The school selects three dimensions of "teaching, learning and supervising" and explores the shining points of the online teaching process from three perspectives of "teachers, students and parents" to carry out teaching style exhibition activities. In the process of network flip teaching design, it can be seen that students are enthusiastic in learning and energetic. They actively participate in online classroom and interact with each other, and most of them can finish their homework assigned by teachers on time. Relying on the construction of provincial quality online open courses, the university 
will lead and drive the construction of university-level quality online open courses, comprehensively deepen the reform of course teaching, promote the deep integration of information technology and education and teaching, and improve the level of education and teaching and the quality of talent training.

\section{Conclusion}

Epidemic under the network of ideological and political theory teaching in our school did dominated by teachers, students as the main body, give full play to students' learning autonomy and enthusiasm, highlight the ideological and political theory course of ideological content, theoretical and affinity, pertinence, through the network to all records and data sorting of the learning process and behavior, realize the education aim of the special period. At the same time, the network of ideological and political theory teaching also reversed transmission during the outbreak we found that the course of the construction of the deficiencies, stood on the historical position of the new era, the ideological and political theory course reform and innovation, must take the initiative to adapt to the era of network, information trend, actively building high-quality goods online courses, using the network platform for online teaching, give full play to its information resource sharing, teaching resources are rich, diverse teaching method, the advantages of the interactive teaching process, and the classroom teaching effective connection and mutual confluence, complement each other, promote the construction of the ideological and political theory course I connotative development.

\section{About the author}

Yan Li, (1984-), female, Han Nationality, from Henan Province; Master, lecturer. Mainly engaged in the ideological and political education teaching and scientific research, the research field for the ideological and political education theory and method research.

\section{Acknowledgement}

[Fund Project 1] This paper is the stage research result of "Affinity Problems and Countermeasures of Ideological and Political Courses in Universities under the Guidance of Water Squeeze and Education Fund" (Ny2019djyb -02), a research topic of Party Construction and ideological and political Science in Guangzhou Nanyang Polytechnic College (Ny2019djyb -- 02).

[Fund Project 2] This paper is the phased research result of the 2019 Engineering research project "Ideological and Moral Cultivation and Teaching Reform of Legal Foundation Course" (NY-2019CQ2KC-09) in Guangzhou Nanyang Polytechnic College.

[Fund Project 3] This paper is the phased research result of 2017 "Ideological and Political Course Group Teaching Team" (NY-2017CQ1TD-03), an innovative engineering research project of Guangzhou Nanyang
Polytechnic College.

\section{References}

1. Shen Zhen. Online Teaching Strategies of Ideological and Political Theory Courses in Universities under epidemic Prevention and Control [J]. Guide to Ideological and Theoretical Education,2020(03)

2. Liu Lijuan. Analysis on Enhancing the Effectiveness of Ideological and Political Theory Teaching in Colleges and Universities during the Epidemic prevention and control period [J]. Journal of Northeast Agricultural University (Social Science edition),2020(03)

3. Liu Xin, Li Qingxia. Major Epidemic Response and the Mission of Ideological and Political Theory Courses in Universities [J]. Research on Ideological and Political Education,2020(03)

4. Yu Hong. The role of ideological and political theory teachers in college online teaching under the epidemic $[\mathrm{J}]$. Beijing Education (Moral Education),2020(04)

5. Wang Weiguo. Reflections on the Reform and Innovation of Ideological and Political Theory Courses in Universities under the normalization of epidemic Prevention and Control [J]. Research on Socialist Core Values, 2020(02)

6. Leng Cuiling, Peng Hao. Reflections on online Teaching of Ideological and Political Theory Courses in Colleges and Universities from the perspective of Anti-Epidemic [J]. Journal of Heze University,2020(03)

7. zhang guangjun. Integration and transcendence of "Internet + teaching" $[\mathrm{J}]$. Education research, 2016 (6)

8. Wang Taozhen, Gao Guoxi. Practice and Thinking of mooC Construction of Ideological and Political Theory Course -- Based on "Ideological and Moral Cultivation" of Fudan University Research on MOOCS and Legal Basis [J]. Research on Ideological Education,2017(06)

9. Li Kidong, Zhao Jianhua. Principle and Application Mode of Mixed learning [J] Research on Audio-visual Education, 2012(7)

10. Wang Pingxia. Analysis on the Blended Teaching Mode of Ideological and Political Theory Courses in Universities in the Era of "Internet + " $[\mathrm{J}]$. Guangxi Social Science, 2017(04)

11. Wu Zhengchun. Exploration on the Reform of mixed Teaching Mode of Ideological and Political Theory Course in Universities based on SPOC [J]. Ideological and Political Education Education research, 2017 (05)

12. Gong Li. Analysis on the Mixed Teaching Mode of Ideological and Political Theory Courses in Colleges and Universities [J]. Party Building and Ideological Education in Schools, 2016(09) 
13. Yang Zhichao. Analysis on the Construction Path of mixed Teaching Mode of Ideological and Political Theory Course in Colleges and Universities [J]. Research on Ideological Education,2016 (6)

14. Wang Hui. Reconstruction and Confusion: Implementation and Evaluation of Blended Teaching in Ideological and Political Theory Courses in Colleges and Universities [J]. Modern Education Science, 2017 (7)

15. Zeng Linghui. On innovation of Network Ideological and Political Education Methods [J]. Party Building and Ideological Education in Schools, 2018(23)

16. Wu Jun. Research on the Application of Flipped Classroom Teaching Model for Ideological and Political Theory Courses in Colleges and Universities [J]. Party Building and Ideological Education in Schools, 2018(18)

17. Wu Yan. "Golden Course" for Building China [J]. Teaching in Chinese Universities, 2018(12)

18. Li Jiao. "Classroom Revolution" and "Flip Synergy" of Ideological and political Theory Course in Colleges and Universities [J]. Beijing Education (Moral Education), 2019(01)

19. Shen Zhen. Research on interactive Teaching of Ideological and Political Theory Course based on Mobile Internet Technology [J]. Guide to Ideological and Theoretical Education, 2017 (11)

20. Sun Kang. "Flipped classroom" based on online open course challenges new ideological and political theory course teachers in universities $[\mathrm{J}]$. Guide to Ideological and Theoretical Education, 2017 (10) 